
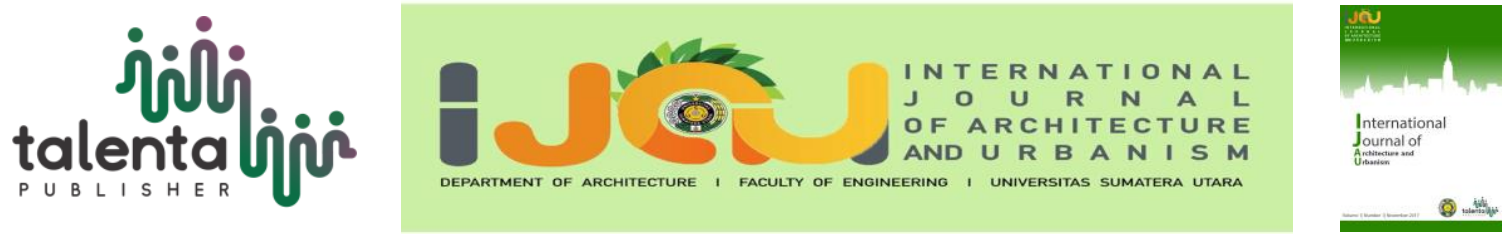

\title{
Medan The Vertical Village Design In Kelurahan Aur (With Ecology Architecture Design Approach)
}

\author{
Ivany Hidayat $^{1 *}$, Wahyuni Zahrah ${ }^{1}$ \\ ${ }^{1}$ Department of Architecture, Universitas Sumatera Utara, Medan, Indonesia
}

\begin{abstract}
Kampung Aur is one of the densely populated settlements located in Medan City Center. This village is located on the banks of the River Deli, District Mimoon Medan, Neighborhood IV. Kampung Aur is a place for the lower middle-class urban community that provides a place for unplanned settlements. This village has the potential to be reorganized while maintaining the traditions of the people. The approach used for the design of this village is Ecological architecture, where the building uses a natural building system, wastewater treatment, and rainwater utilization.
\end{abstract}

Keyword: vertical, village, ecology, architecture

\section{Introduction}

The dynamic development of the city area brings many impacts to the urban community's life patterns. Along with the growth of the population in urban areas, the need for the provision of infrastructure and facilities of settlements will increase as well, either through new improvements or development. This causes the carrying capacity of existing settlement facilities and infrastructure began to decline, resulting $n$ the slums. One of the slums in the city of Medan is Kampung Aur which is a settlement located on the outskirts of the Deli River in Aur Village Medan Maimun District. Kampung Aur is a place for the urban community of middle to lower class. The orientation of settlements in Kampung Aur is influenced by the Deli river flow along the area. The location of Kampung Aur which is still in the center of Medan city makes it a portrait of an urban settlement that grows unplanned. The increasing number of residential needs make the riverbanks a target for low-income people.

In accordance with the established government regulation, That River Border Line (GSS) of 15 m. But in Kampung Aur is not in accordance with the rules of reference. Then the problem of flooding also occurred in Aur Settlement due to the lack of Green Open Space (RTH), the unavailability of garbage dumps (TPA), inadequate public facilities, and low livelihoods. Then

\footnotetext{
*Corresponding author at: Department of Architecture, Faculty of Engineering, Universitas Sumatera Utara,

Jalan Perpustakaan Gedung J07, Medan 20155, Indonesia

E-mail address: ivanyhidayat95@gmail.com
} 
the use of building materials that are not in accordance with the requirements of materials for housing construction according to the Head of Minister of Health No.829 / Menkes / SK / VII / 1999. To solve these problems, it needs a plan/strategy for re-arrangement of a comfortable, safe, clean and orderly settlement area (government regulation no.4 of 1988). As well as putting the original inhabitants without changing their old social behavior and lifestyle/culture, and apply the ecological village principle.

\section{Literature Review}

\subsection{Terminology}

Vertical Village Design in Kelurahan Aur of Medan City is the process of planning a building, and environment with a system of structural-functional into a vertical or horizontal form of settlement by maintaining the tradition of Kampung Aur society.

\subsection{Location and Site}

The site is located in Neighborhood IV Medan Maimun Subdistrict, which is the Development Construction Area D (WPP D), whereas the center of core city development which is landed at Government Center, Settlement, Office, Education, and Indoor Recreation. Kelurahan Aur has ten environments consisting of 2,496 families with a total population of $\pm 9,484$ inhabitants. Geographically, Kampung Aur is located at $3^{\circ} 344^{\prime} 52$ "LU and $98^{\circ} 40^{\prime} 44^{\prime \prime}$ BT, which is located in the center of Medan (Figure 1).

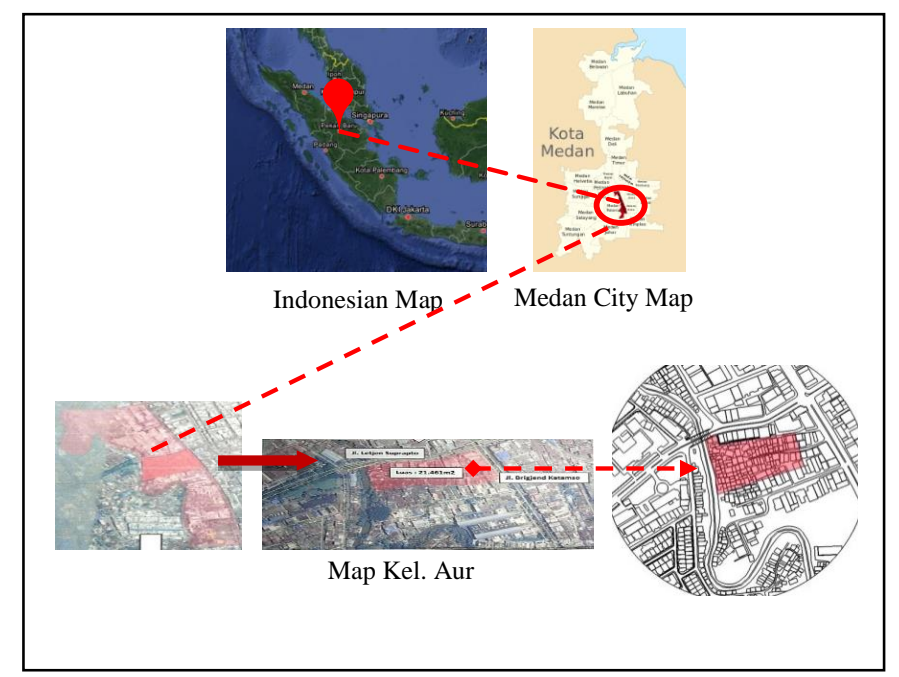

Figure 1. Location Map Kampung Aur

(Source: Google Earth and Author, 2017)

\subsection{Theme Elaboration}

The theme for designing "Aur Vertical Village" is Ecological Architecture. Ecological architecture is an environmentally friendly development that utilizes the potential of nature as much as possible [1]. The concept can be applied in the city of Medan, given the enormous intensity of development and severe environmental damage caused by development. This 
approach keeps maintaining old lifestyle and culture. The plan is aimed to improve socioeconomical aspects of the residents as well as building and environment quality [3].

\section{Methodology}

The method used in the Vertical Village design project in Kelurahan Aur is site selection by collecting data from literature study, comparative study, field survey, social mapping, community activities, and interviews. To approach the concept of the method of analysis and qualitative. And the final approach of the design is the conclusion to be translated into the design of the final draft drawing. The selection of project sites is linked to the main design issues of low-income settlements in densely populated urban areas, one of which is the slums with structural reviews of the Medan city. Then conduct a direct field survey with social mapping and conduct interviews. Then proceed to the concept. The results are then processed into a concept of planning and design in the form of ideas and problem-solving strategies in the form of basic ideas/basic concepts associated with the basic theme of the design. The merger of all these concepts into working drawings that have been measured in the form of drawings, looks, pieces, plans, details, and design perspective.

\section{Result and Discussion}

\subsection{Project Description}

This project is located in the Kampung Aur Kecamatan Medan Maimun which is located in the core of Medan City. The title of this project is "Vertical Village Design in Kelurahan Aur Medan City (with Ecological Architecture design Approach)." Location This design is located in Kelurahan Aur which is one Village in District Maimun Medan, which has a total area of \pm $60 \mathrm{Ha}$. Kelurahan Aur has ten environments consisting of 2,496 families with a total population of $\pm 9,484$ inhabitants. Existing functions around the site there are historic buildings, shophouses, offices, and settlements. The average height of the building is about 3-4 floors. Its location on the banks of the Deli River makes the area becomes slum and irregular.

\subsection{Analysis of Activity Systems}

The activities of villagers form the space. By analyzing the system of activities that occur in the village of Aur, space and facilities can be identified. The are two activities, occurred, namely communal activities and individual activities. Communal activities conducted every day. The citizens of kampung Aur much spent to socialize in the stalls and gathered in front of the terrace of the house residents. Comunity, especially at that location near the river, often do cooperation action. This action is done once a week, at least once a month. Citizens perform daily activities by washing clothes in the river. Most villagers are traders. Most of them sell food stalls, grocery stores, and selling spices (Figure 2). 


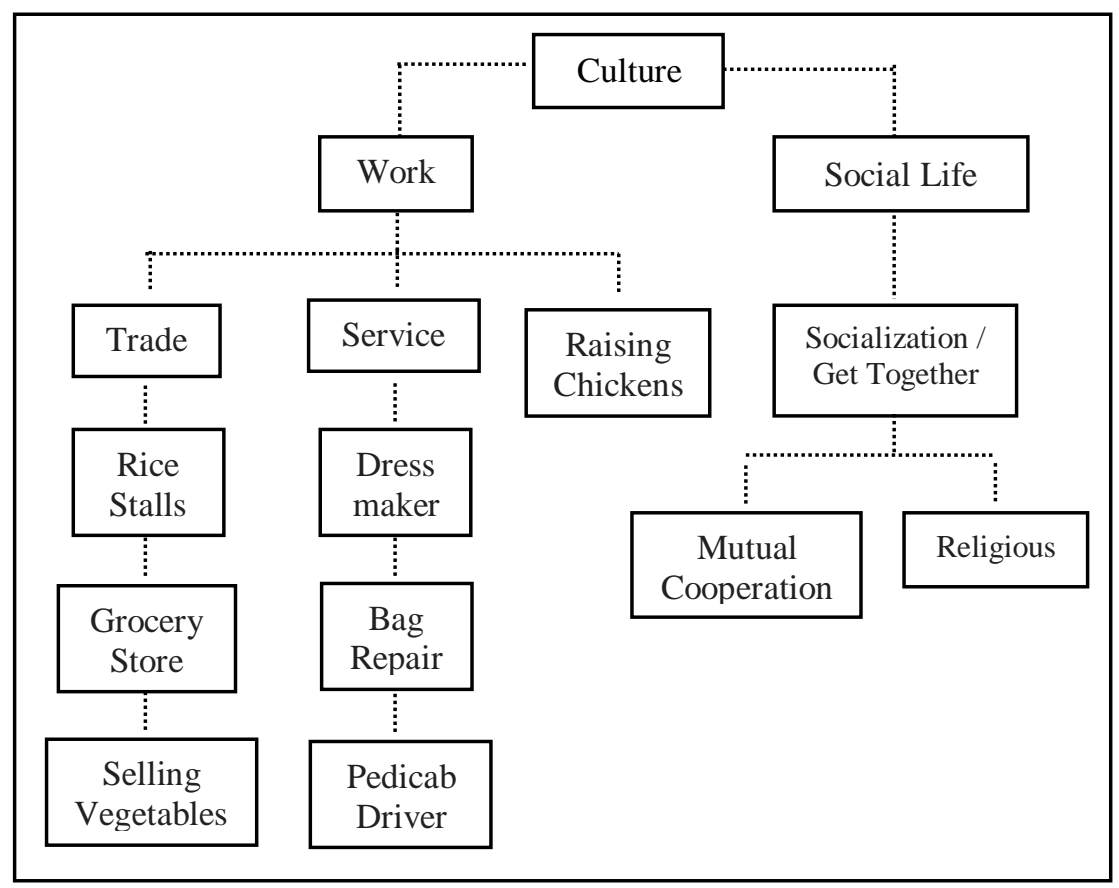

Figure 2. Schema Analysis of Activity System

\subsection{Site Analysis}

The site is located in a hot, humid tropical climate. The temperatures ranging from $25^{\circ}-33^{\circ} \mathrm{C}$ with humidity around $60-95 \%$ and wind speeds between ten $\mathrm{km} /$ hour. The secondary arterial road is 4 meters, has green coverage $25 \%$ and building coverage $60 \%$. Based on the topography of Kampung Aur area, the Aur settlement is placed on sloping land. Low contour areas are on the banks of the River Deli. Kampung Aur is situated in a fairly contoured soil at the bottom of the river bank, so it is a suitable condition to install bio-waste water treatment including ecodrainage processing (Figure 3).

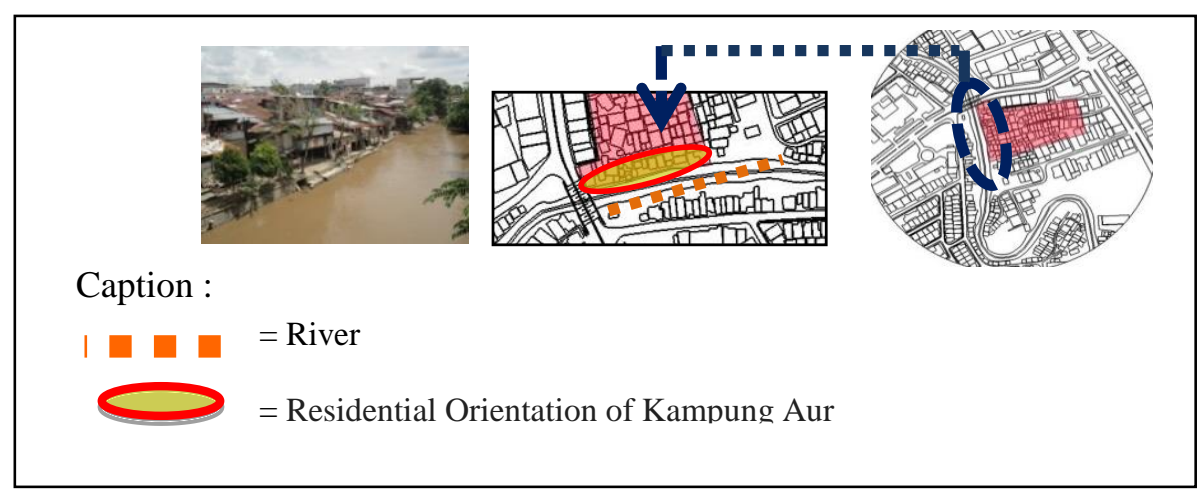

Figure 3. Conditions on the banks of the River

\subsection{Basic Concept}

The basic concept used is Ecological Design that applied to the principles of a vertical village. The concept is implemented to maintain the cleanliness of the River, maintaining a healthy kampung environment, not preventing the river, maintaining social ties and cultural tradition. 
The concept expresses the safe, comfortable and clean environment for the residents. The buildings that apply ecological architecture provides an energy saving \& low-cost building operation.

\subsection{Design approach}

The design approach to the Kampung Vertical design is the Ecological Architecture characterized by the following ways: developing vegetation well that can modify climate and reduce air pollution, making green open space that can reduce flooding, implement Recycle, Reuse, and Reduce for water. The use of rainwater for daily needs that can help ease the burden on the people. For natural building systems, the orientation of the building is laid between the path of the sun and the wind. The openings of the building are oriented to South and North [2], to avoid direct sunlight expose and day get lighting and natural cooling (Figure 4).

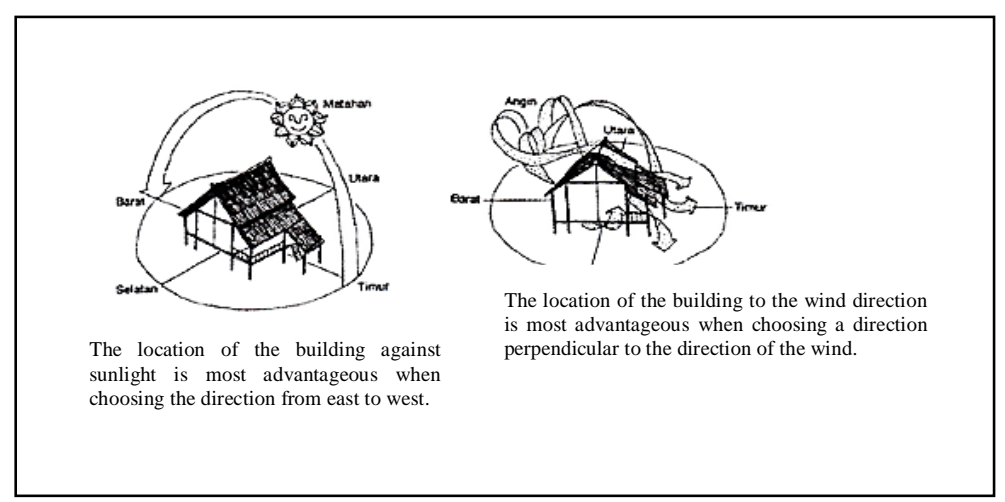

Figure 4. Building Position that blends with Climate.

( Source: Heinz Frick, 2007 )

Public space - residential unit, The organization of function are as follows: The first floor is used as a public space and marketplace. The housing consists of some blocks of vertical village mass that are integrated with other dwellings [4]. There is a communal space on each floor in the middle to accommodate people tradition (Figure 5). The urban farming is arranged as that green path united with nature. In this garden, there is a park area that can be used as recreation area to enjoy the natural atmosphere. This area is supported by seating facility and ornamental plants. So that citizens and children can play while interacting each other. Besides they can watch the activities undertaken in the Deli River directly (Figure 6). The utility system uses an eco-drainage system and biological wastewater treatment. The rainwater that is collected is distributed to the rainwater tank after being filtered, then distributed to the housing unit for daily needs. Wastewater treatment using a biofilter system. Biopori is installed to prevent flooding and to send rainwater to the underground back aquifer (Figure 7). 


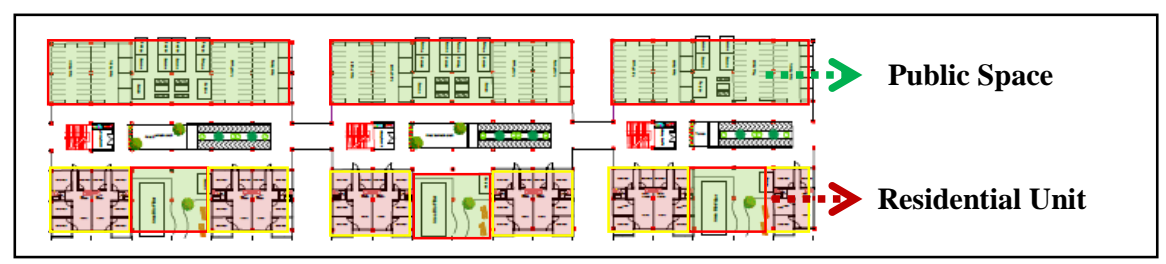

Figure 5. Ground Floor of the Building

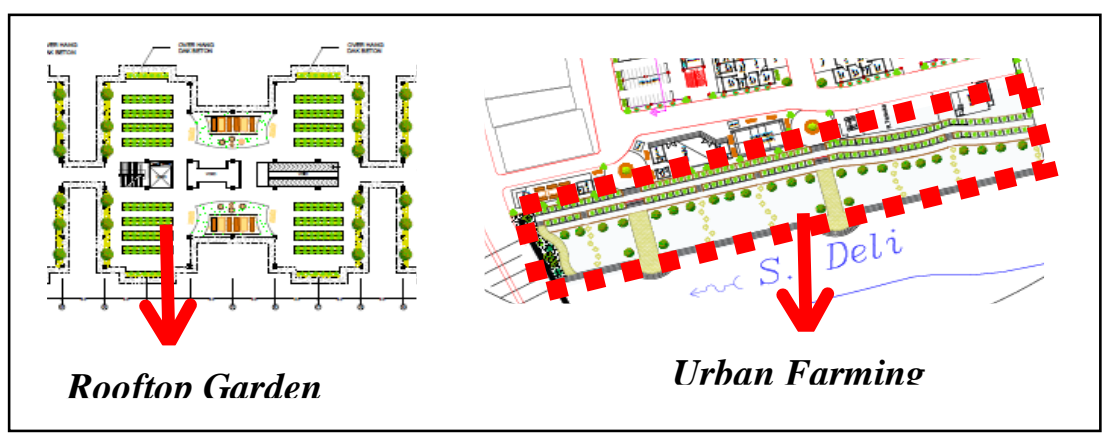

Figure 6. Urban Farming Area

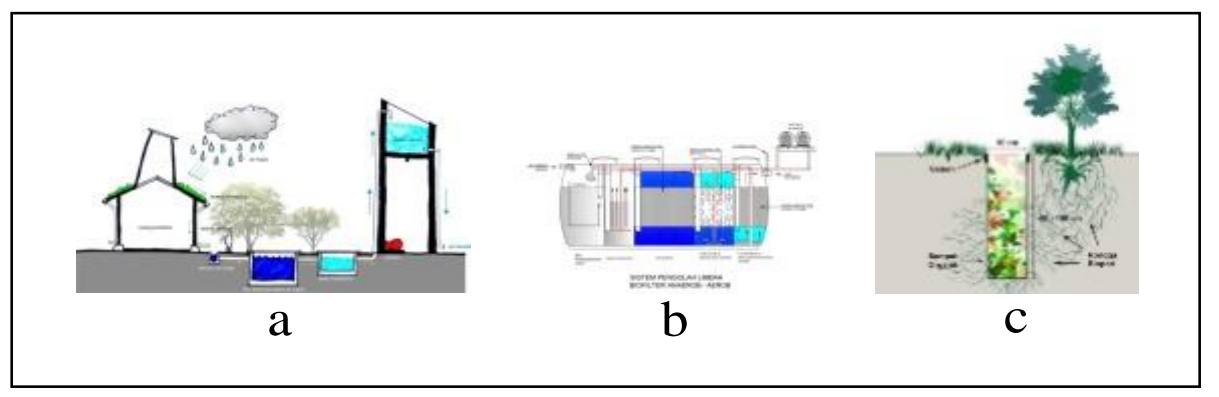

Figure 7. a. Rainwater Systems, b. Biofilter Systems, c.Biopori.

( Source : a.studiopie.blogspot.id, b.sejahterarayafiber.com, c.Kompasiana.com)

\subsection{Building \& Spatial arrangement}

The vertical Aur village is made up of six building blocks that interconnect with the other buildings. Each building consists of 5 floors. Each floor is connected to the next building by a bridge. The zoning is arranged to be the higher, the more private. Upstairs is a roof garden people can use it for gardening. The housing is composed of some based on clusters residential type and family division. There are two types of division, namely small type of $4 ?^{\mathrm{c}}$ and big type of $60 \mathrm{~m}^{2}$ (Figure 8). 


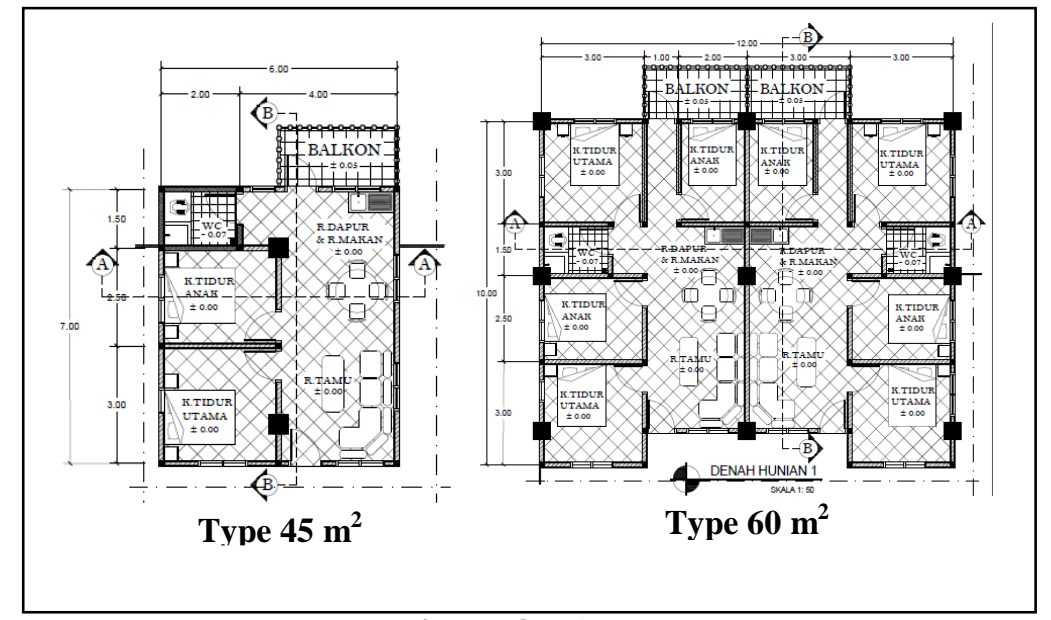

Figure 8. Plan

On the first floor, the main building consists of public zones and services, where there is only retails, functions parking areas for residents, Some housing units and children's play areas (Figure 9). The second floor consists of four private areas of residential units of Aur villagers, common laundry areas and communal space on each floor (Figure 10 ). On the fifth floor, there is a rooftop garden for gardening. The harvest can be sold to complement the people's income. In the rooftop garden, there is also a gathering area as well as a resting place for gardening residents (Figure 11).

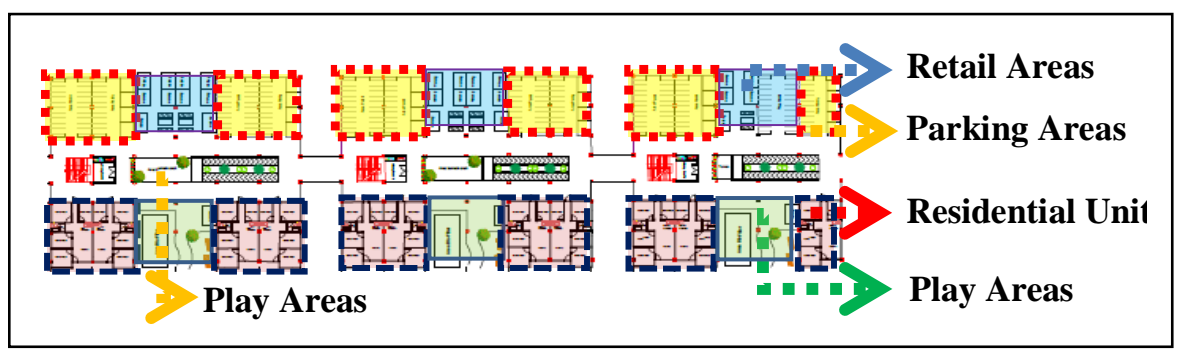

Figure 9. Floor Plan

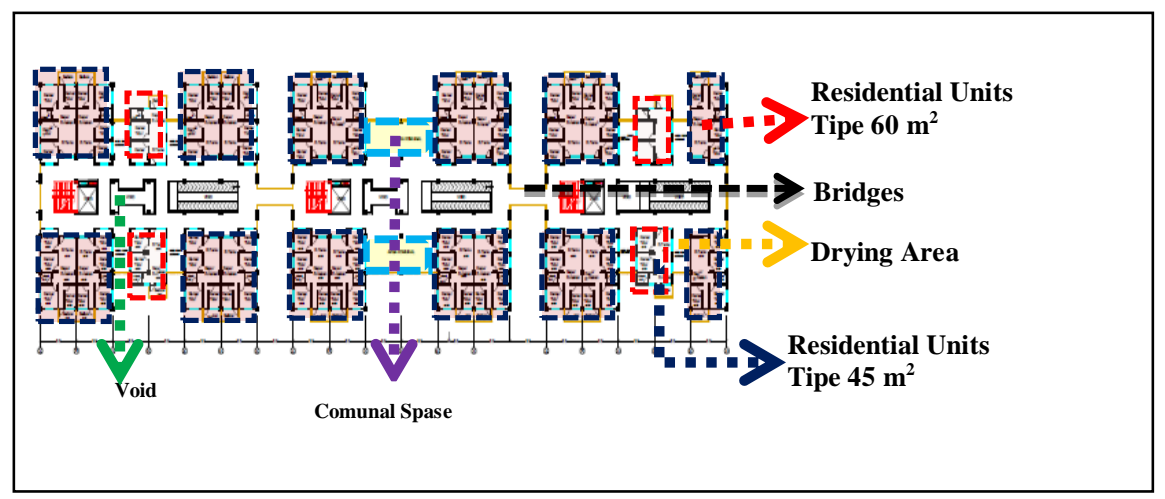

Figure 10. 2-4 Floor Plan 


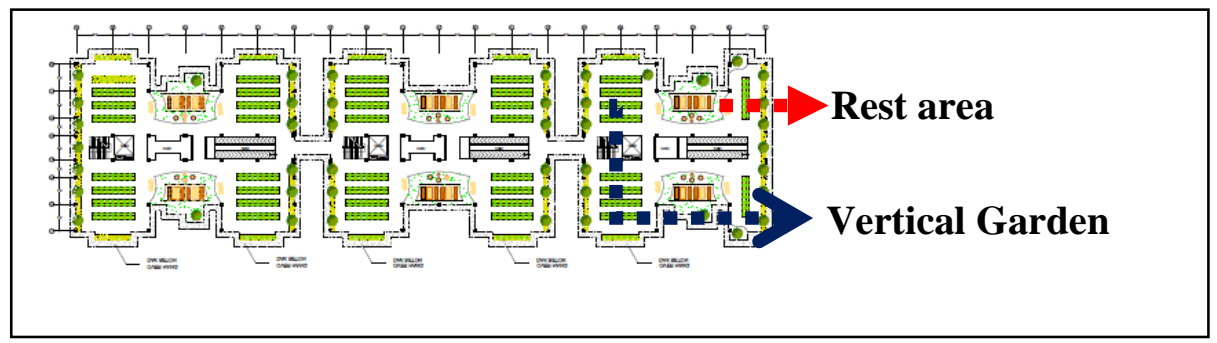

Figure 11. Roof Top Garden

\subsection{Mass and appearance}

For building masses, the designer chooses the single loaded void in the center for natural lighting and air conditioning (Figure 13). The building's facade is formed by a natural building system approach that implements the ecological architecture. The materials used are brick. In this building, there is a vertical garden and wastewater treatment and drainage system ( Figure 12).

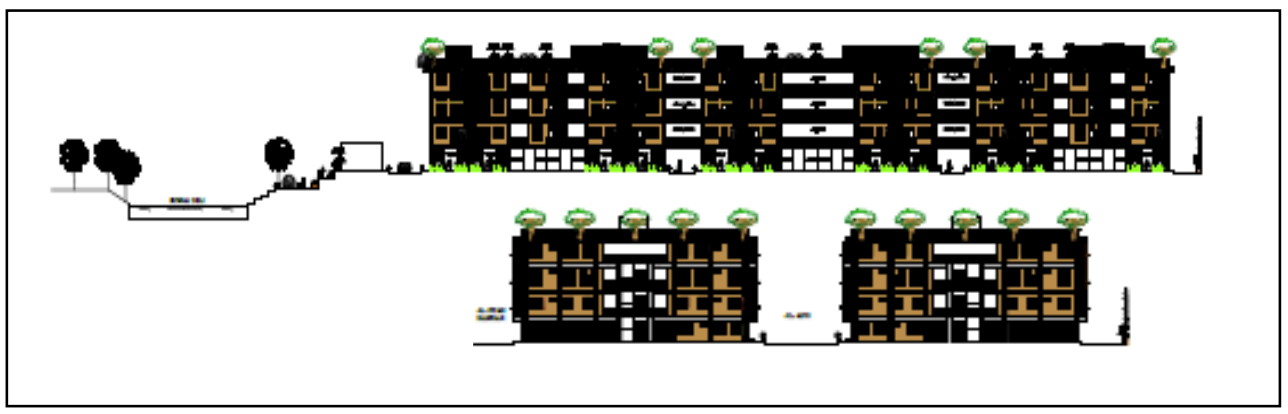

Figure 12. Looked Residential Village

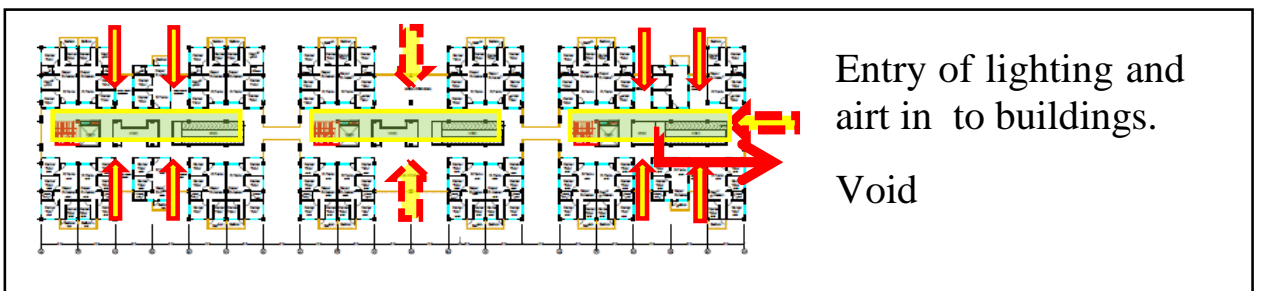

Figure 13. The Floor Plan

\subsection{Site Design/concept exterior space}

Public spaces are located in the first-floor area which is used as a commercial place for residents, but there are also some residential units. Also, there are Mosques, Hall, Guard Post, food stalls and sports area located close to the river. For the green open spaces designed for the Aur, the village is referred to the ecological concept and government regulations; the area is situated adjacent to the river so that the atmosphere blends with nature. The green path area, there is a park with seating facilities that can be used as a family recreation to enjoy the natural atmosphere. So that citizens or children can play while interacting each other and can see the 
activities undertaken in the Deli River directly. The area is also urban farming zone. And The circulation of roads is arranged around the building to control the environment, as well as the concept of buildings that blocked the type of occupancy based on the division of the head of the family (Figure 14).

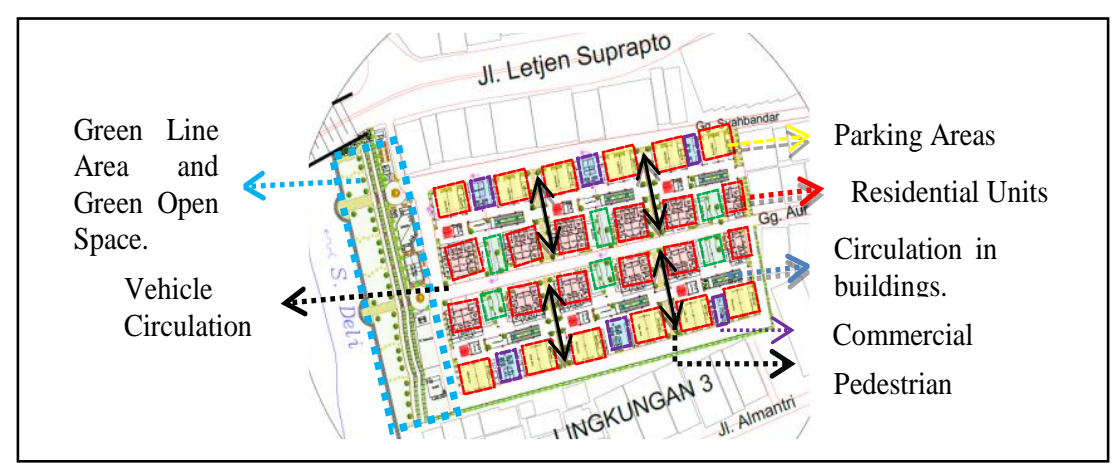

Figure 14. Site Plan

The vehicle access is through Gang Aur and Gang Syahbandar that can directly go to the parking area of vehicle and residents, then go directly to Jalan Letjen Suprapto. There is a pedestrian path to ensure pedestrians can walk safely (Figure 15).

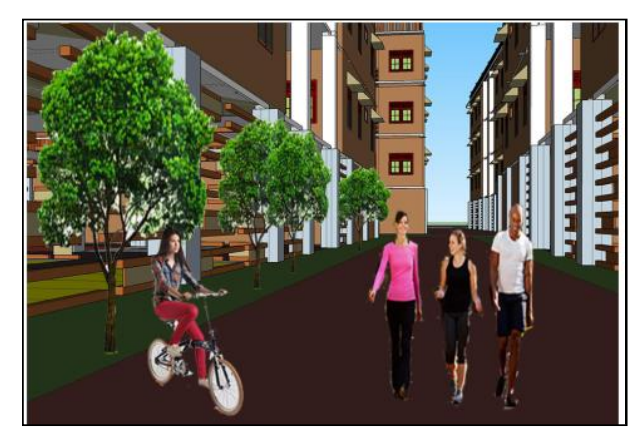

Figure 15. Pedestrian Circulation.

\subsection{Building Structure}

The structure of this vertical kampong is divided into three parts: Lower structure using pile foundation, the structure of building body using rigid frame structure, and roof structure using the concrete roof, and wall brick structure as structural reinforcement ( Figure 16 ). 


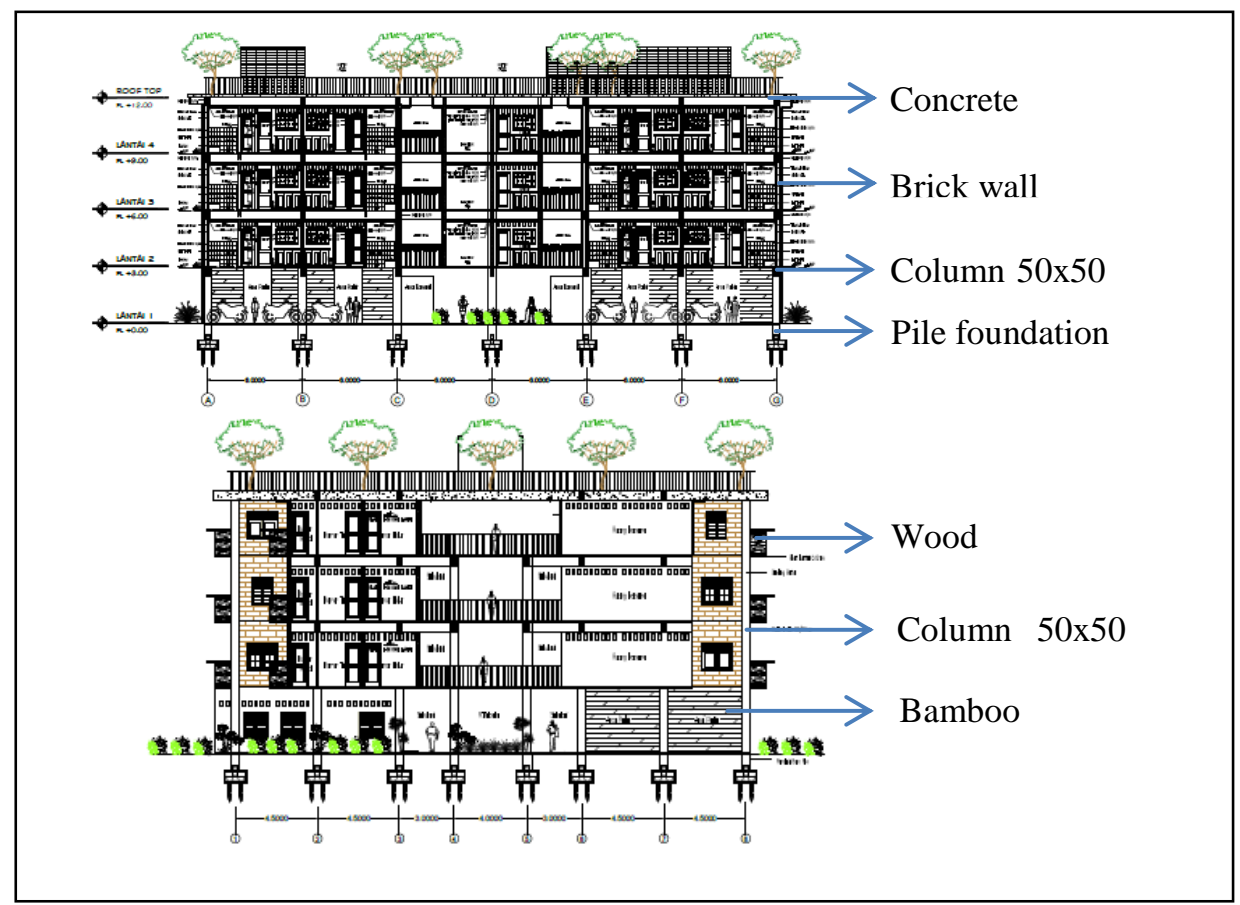

Figure 16. Building Structure

\section{Conclusion}

Ekologi Vertical Kampung was built by applying the planning of communal spaces, natural building system, and ecological utility. Also, vegetation arrangement in this can enhance the environmental quality of buildings in the area. Vegetation can improve microclimate and reduce air pollution. The project tries to maintain existing activities, such as socializing between citizens and working together. There is a commercial area as a container for trade and services as well as urban farming to help to improve the community income. Green open space is used as a catchment area to prevent flooding that is integrated with public facilities and park area in the Deli River as a family recreation area.

\section{Acknowledgment}

This research is part of the requirement to obtain a bachelor's degree in Architecture Department, Universitas Sumatera Utara.

\section{REFERENCES}

[1] C. Damayanti. Pengertian arsitektur ekologi, arsitektur biologis dan arsitektur lingkungan. (online) https://cicidamayanti.wordpress.com/2015/10/06/pengertian-arsitektur-ekologiarsitektur-biologis-dan-arsitektur-lingkungan. 2015.

[2] H. Frick. Dasar-dasar arsitektur ekologis (Vol. 1). Kanisius, 2007.

[3] A. Setiadi. Arsitektur Kampung Tradisional. Universitas Atma Jaya Yogyakarta. 2010.

[4] Yu sing. Keberagaman Kampung Vertikal. (online) http://rumahyusing.blogspot.co.id/2011/01/keberagaman-kampung-vertikal.html. 2011. 